Bull. Fac. Agaric, Cairo Univ., 68:333-344 (2017).

\title{
SYMBIOTIC NITROGEN FIXATION UNDER INTEGRATED ORGANIC-MINERAL NITROGEN APPLICATION ON PEANUT IN SANDY SOIL
}

(Received: 1.11.2017)

\author{
By \\ H. M. El-Egami, Y.A. El-Tahlawy and S. Y. S. El-Sayed \\ Agricultural Microbiology Research Department, Soils Water and Environmental Research Institute \\ Agriculture Research Center Giza, Egypt
}

\begin{abstract}
A field experiment was conducted on a sandy soil at Ismailia Agricultural Research Station, Ismailia Governorate, Egypt during the summer season of 2016 to study the influence of organo-mineral fertilizer application on nodulation status, yield and yield components of peanut. Four different types of composts originated from different raw materials (cotton stalks, rice straw and bagasse) were integrated with different doses of mineral nitrogen $(0,25,50$ and 100\%). Application of any type of compost resulted in enhancement of the nodulation status, plant growth, peanut yield and its components. However, application of rice straw and cotton stalk composts attain the highest values of all the studied parameters. Moreover, the synergy between 50\% mineral-N and 50\% from any type of compost was superior in all the studied parameters. These fertilization patterns may be considered the most effective strategy for reducing chemical fertilizer, conserving soil fertility and supporting the sustainable agriculture system under sandy soil conditions for producing peanut.
\end{abstract}

Key words: peanut, nitrogen fixation, organo-mineral n-fertilizer.

\section{INTRODUCTION}

Peanut (Arachis hypogaea L.) is considered one of the most important sources of edible oil in the world. The seeds have high nutritive value for human consumption and green leaves are used as hay for livestock (Abdalla et al., 2009). Peanut seeds contain high oil content (50\%), which is utilized in different industries, in addition to 26-28 $\%$ protein, $20 \%$ carbohydrates and 5\% fiber (Fageria, et al. 1997). The cultivated area of peanut in Egypt during 2011-2012 season was about 62.000 hectares (FAO, 2013). Recently, this crop has been given a great attention due to its suitability for growth in the newly reclaimed sandy soil areas in Egypt.

Most of the newly cultivated area in Egypt is sandy soils which require high rates of chemical fertilizers, aiming to maximize seed yield for human feeding and straw yield to be used in animal feeding and deficient in organic matter as well (Abdel-Wahab et al., 2003). Organic materials including compost are considered the vital soil amendment, as a source of major and minor nutrients, and as a slow release fertilizer (Hoitink and Grebus, 1994).

Nutrient balance is the key component to increase crop yields. Nutrient mining from the soil, deteriorated crop productivity and ultimately soil fertility could be compremized resulted by excess and imbalanced usage of nutrients. Replacement of these nutrients through organics and in combination with organic (organic manures, crop residues and biofertilizers) and inorganic inputs has a direct impact on soil fertility and crop productivity (Datt et al., 2013).

Due to the intensive farming, Egypt is known as a heavy consumer of chemical fertilizers. The immediate application of organic manures and biofertilizers is frequently recommended firstly for improving biological, physical and chemical properties of soil, and to get high yield and clean agricultural produce free from undesirable heavy metals and other pollutants (Mahrous et al., 2015). 
However, integrated application is needed as alternate nutrient sources for sustaining the desired crop productivity. Tiwari (2002), Doran (1995) and Datt et al. (2013) defined the integrated farming system as an agricultural system conceived to have the least impact on the environment.

Shehata (2001) studied the independent application and the combined effects of composts prepared from four organic wastes namely, water hyacinth, pea, orange and chicken manure on squash growth, nutrient contents and fruit yield. He found that the application of compost, which contains the four wastes significantly increased all growth parameters, i.e. vine length, the number of leaves, fresh and dry weight of branches and leaves and fruit yield. Chemical analysis of squash fruits revealed beneficial increase in $\mathrm{N}, \mathrm{P}$ and $\mathrm{K}$ due to organic manure application.

On the other hand, many researchers reported positive effects on crop yield following the combined application of compost and inorganic fertilizer (Keeling et al., 2003 and Abdel-Wahab, 2008). There are several explanations for the synergy between compost and fertilizer including alterations of soil water characteristics and mycorrhizal associations (McCallum, 2000). Alternative explanation involve the chemistry of the composts themselves, especially the water soluble fraction, where water extractable humic substances are found in soils and arise through bacterial and fungal action on organic matter over many months and these have been shown repeatedly to be beneficial to plant growth (Ayuso et al., 1996 and Chen et al., 1999).

Symbiotic nitrogen fixation by legumes plays an important role in sustaining crop productivity and maintaining the fertility of the semi-arid lands (Desoky et al., 2011). Vessey and Buss (2002) reported that the most commonly implicated role to stimulate legume-Rhizobium symbiosis in photohormones inducing stimulation of root growth, to provide more sites for rhizobia infection and nodulation. Mahrous et al. (2015) found that the un-inoculated peanut had the least nodulation status and nitrogenase activity. In thies case, inoculation of peanut seeds with Bradyrhizobium exerted considerable improvement in the number and mass of root nodules, and increased the rate of acetylene reduction and all growth characters. In this respect, Sulfab et al. (2011), showed that either organic manure alone or with Rhizobium inoculation plus $20 \mathrm{~kg}$ N/ha significantly increased groundnuts nodulation and early pod formation over the control. Increasing groundnut yield and its components by using the integrated action of both bio-organic and chemical fertilizers were reported by many researchers.

Nitrogen at the rate of $20 \mathrm{~kg} \mathrm{~N} / \mathrm{ha}$ via inoculation with rhizobia coupled with either manures resulted in a significant increment in shoot and root dry weights compared to the control. These treatments also influenced groundnuts shoot $\mathrm{N}$ and $\mathrm{P}$ accumulation and resulted in significantly the highest pod and straw yields over all other treatments under irrigated and rain fed conditions (Mahrous et al., 2015).

Therefore, in the light of the abovementioned review, the present study aimed to investigate the effect of four types of enriched compost integrated with different levels of inorganic nitrogen fertilizer on symbiotic nitrogen fixation of peanut under sandy soil conditions .

\subsection{Materials \\ 2.1.1. Organic fertilizer}

2. MATERIALS AND METHODS

Composts were supplemented from Soil, Water and Environment Research Institute (SWERI), ARC, Giza, Egypt. The composts were prepared from cotton stalks, rice straw, bagasse and their mixture as primary materials as described in Owis et al. (2016). Farmyard manure, rock phosphate, feldspar, bentonite, urea and elemental sulfur at rates of $10,5,5,10,1$ and $1 \% \mathrm{w} / \mathrm{w}$, respectively, as well as vinasse solution and lignocellulytic inoculant (mixture of Trichoderma harzianumand, Trichoderma viridi) at the rates of $1 \% \mathrm{v} / \mathrm{w}$, respectively, were added as bulking agents and/or amendments. After three months of composting, all heaps were enriched with a mixture of rhizobateria inoculant (Bacillus polymyxa, Serratia mercescens and Pseudomonas fluorescens) and left for curing 30 days. The main physicochemical characteristics of the four types of compost are shown in Table (1).

\subsubsection{Inorganic fertilizers.}

Mineral nitrogen fertilizer was added as ammonium sulfate $(20.5 \% \mathrm{~N})$. All treatments received superphosphate $\left(\begin{array}{lll}15.5 \% & \mathrm{P}_{2} \mathrm{O}_{5}\end{array}\right)$ and 
Table (1): Physico-chemical characteristics as well as humification and some maturity indices of the used compost.

\begin{tabular}{|c|c|c|c|c|}
\hline $\begin{array}{ll}\text { Character } & \text { Compost type }\end{array}$ & $\begin{array}{c}\text { Cotton } \\
\text { stalk }\end{array}$ & Rice straw & Bagasse & Mixture \\
\hline Water holding capacity (\%) & 223.3 & 141.5 & 152.6 & 167.5 \\
\hline Bulk density $\left(\mathrm{kg} / \mathrm{m}^{3}\right)$ & 410.0 & 600.0 & 300.0 & 390.0 \\
\hline pH $(1: 10$ extract $)$ & 7.95 & 6.77 & 6.41 & 7.12 \\
\hline E.C $(d S / m)$ & 4.28 & 5.53 & 6.32 & 5.30 \\
\hline Organic carbon (\%) & 22.85 & 23.60 & 29.40 & 27.25 \\
\hline Organic matter (\%) & 39.3 & 40.59 & 50.56 & 48.50 \\
\hline Total-N $(\%)$ & 1.44 & 1.42 & 1.49 & 1.37 \\
\hline Total-P (\%) & 0.60 & 0.46 & 0.61 & 0.60 \\
\hline Total-K (\%) & 2.18 & 1.60 & 1.81 & 1.72 \\
\hline $\mathrm{C} / \mathrm{N}$ ratio & 15.86 & 16.61 & 19.73 & 19.89 \\
\hline $\mathrm{N}-\mathrm{NO}_{3}^{-}(\mathrm{mg} / \mathrm{kg})$ & 391.7 & 371.0 & 431.9 & 425.2 \\
\hline $\mathrm{N}-\mathrm{NH}_{4}^{+}(\mathrm{mg} / \mathrm{kg})$ & 465.1 & 441.0 & 506.0 & 570.0 \\
\hline Total soluble-N (mg/kg) & 757.8 & 712.0 & 937.9 & 995.2 \\
\hline Available-P (mg/kg) & 361.5 & 311.0 & 316.5 & 302.8 \\
\hline Available-K (mg/kg) & 715.8 & 613.5 & 825.4 & 714.5 \\
\hline $\mathbf{E}_{4} / \mathbf{E}_{6}$ ratio & 2.32 & 2.54 & 1.97 & 2.12 \\
\hline $\mathrm{NH}_{4}^{+} / \mathrm{NO}_{3}^{-}$ & 1.18 & 1.18 & 1.17 & 1.33 \\
\hline DHA (mg TPF/100g) & 86.5 & 89.8 & 91.7 & 90.4 \\
\hline GI for Cress & 92.8 & 79.5 & 85.0 & 79.8 \\
\hline GI for Barley & 112.2 & 89.7 & 111.6 & 98.6 \\
\hline
\end{tabular}

potassium sulfate $\left(48 \% \mathrm{~K}_{2} \mathrm{O}\right)$ at the rates of $200 \mathrm{~kg}$ and $50 \mathrm{~kg} / \mathrm{fed}$, respectively.

\subsubsection{Plant material}

Peanut (Arachis hypogaea), cv., Giza 5, was kindly provided from the Field Crop Research Institute, Agriculture Research Center (ARC), Giza, Egypt.

\subsubsection{Preparation of Rhizobium inoculum.}

Peanut seeds were inoculated with Bradyrhizobium sp., which was kindly provided from Biofertilizers Production Unit, Agric. Microbiology Dep., Soils, Water and Environment Research Institute (SWERI), ARC, Giza, Egypt, through using solid inoculant at the rate of 300 $\mathrm{g} / 50 \mathrm{~kg}$ seeds with $16 \%$ Arabic gum solution as sticking agent.

\subsubsection{Field experiment and treatment}

Field experiment was conducted during the summer season of 2016 on sandy soil at Ismailia Agricultural Research Station, Ismailia Governorate, Egypt to study the influence of different types of composts in synergy with different levels of inorganic $\mathrm{N}$-fertilizer on nodulation, growth, yield and yield components. The main physical, chemical and biological properties of the experimental soil are shown in Table (2). A randomized complete block design with three replicates was used. Irrigation was done using sprinkle system. The combinations between compost types and mineral fertilizer as rates of organic inputs were developed based on its inorganic $\mathrm{N}$ concentration as shown in Table (3).

Five guarded plants were taken from each plot at 75 days after sowing to determine nodulation status, shoot dry weight and its total $\mathrm{N}$-content. At harvesting time, ten guarded plants were taken from each plot to determine yield components, namely pod number/plant, 100-seed weight and crude protein percentage. Plants in the middle three ridges of each plot ( $3 \mathrm{~m}^{2}$ area) were harvested to determine the yield of pods, seeds and straw $(\mathrm{kg} / \mathrm{fed})$.

\subsection{Methods of analysis}

Soil and compost characteristics were determined according to Piper (1950) and page et al. (1982). Total-N content and crude protein 
content in plant tissues and seeds were assayed according to Page et al. (1982). Nitrogenase

Table (2): The main physical, chemical and biological properties of the experimental soil.

\begin{tabular}{|c|c|}
\hline Character & Value \\
\hline Particle size distribution: & \\
\hline$\overline{\text { Sand ( \% ) }}$ & 90.30 \\
\hline Silt （\% ) & 4.90 \\
\hline Clay ( \% ) & 4.80 \\
\hline Texture grade & Sandy \\
\hline $\mathrm{CaCO}_{3}$ & 1.72 \\
\hline S.P $(\%)$ & 21.10 \\
\hline pH (soil paste) & 7.57 \\
\hline E.C. $\left(\mathrm{dS} / \mathrm{m}\right.$ at $\left.25^{\circ} \mathrm{C}\right)$ & 0.32 \\
\hline Soluble cations $(\mathrm{meq} / \mathrm{L})$ : & \\
\hline$\overline{\mathbf{C a}^{++}}$ & 0.84 \\
\hline $\mathbf{M g}^{++}$ & 0.52 \\
\hline $\mathbf{K}^{+}$ & 1.51 \\
\hline $\mathrm{Na}^{+}$ & 0.15 \\
\hline Soluble anions $(\mathrm{meq} / \mathrm{L}):$ & \\
\hline $\mathrm{CO}_{3}^{--}$ & 0.00 \\
\hline $\mathrm{HCO}_{3}^{-}$ & 1.72 \\
\hline $\mathrm{Cl}^{-}$ & 0.68 \\
\hline $\mathrm{SO}_{4}^{--}$ & 0.62 \\
\hline Organic matter $(\%)$ & 0.53 \\
\hline Total-N ( \% ) & 0.03 \\
\hline Available-P (mg/kg)) & 5.95 \\
\hline Available -K (mg/kg) & 58.7 \\
\hline Available -Fe (mg/kg) & 2.30 \\
\hline Available -Mn (mg/kg) & 0.50 \\
\hline Available -Zn (mg/kg) & 0.60 \\
\hline Log No. of bacteria & 4.86 \\
\hline Log No. of fungi & 3.56 \\
\hline Log No. of actinomycetes & 4.11 \\
\hline $\begin{array}{l}\text { Dehydrogenase activity } \\
\text { (mg TPF/100g) }\end{array}$ & 8.70 \\
\hline
\end{tabular}

enzyme activity in fresh roots was measured using acetylene reduction assay as described by Hardy et al. (1973). All data of plant parameters were statistically analyzed according to Snedecor and Cochran (1980).

\section{RESULTS AND DISCUSSION}

\subsection{Vegetative stage}

Vegetative stage was evaluated via nodulation status, shoot biomass and their $\mathrm{N}$-content of peanut plants grown on sandy soil 75 days after sowing. Fig. (1) demonstrated that mineral $\mathrm{N}$ fertilizer integrated with organic $\mathrm{N}$ led to significant increase in nodulation status which is expressed by nodule number, nodule dry weight and nitrogenase enzyme activity in comparison to sole application of mineral nitrogen fertilizer. However, the application of zero mineral $\mathrm{N}$ and $100 \%$ of any type of compost surpassed the other treatments for nodule number, particularly zero $\mathrm{N}$ and $100 \%$ mixture of the three types of compost. The peanut plants fertilized with $50 \%$ mineral $\mathrm{N}$ and $50 \%$ compost gave the highest nodule dry weight and nitrogenase enzyme activity, especially with rice straw compost. While, the application of $100 \%$ mineral $\mathrm{N}$ fertilizer showed the least effect on nodulation status, where the least values of nodule number, nodule dry weight and nitrogenase enzyme activity were recorded.

The positive effect of compost combined with $\mathrm{N}$ fertilizer on nodulation status may be attributed to the vital role of active organic compounds in improving the physical, chemical and biological properties of sandy soil such as increasing of nutrients availability, microbial activity in rhizosphere and enhancing the root proliferation and consequently boosting the intact nodulation pattern. These results were in harmony with (Abdel-Wahab et al., 2003 ; Abdel -Hafez and Abo El Soud, 2007).

Table (3): The combinations between compost types and mineral fertilizer.

\begin{tabular}{|c|c|c|c|c|c|}
\hline Combinations & Mineral fertilizer & \multicolumn{4}{|c|}{ Compost type (ton/fed) } \\
\cline { 3 - 6 } Compost : Mineral & $(\mathrm{kg} /$ fed) & Cotton stalks & Rice straw & Bagasse & Mixture \\
\hline $100 \%:$ zero & - & 2.78 & 2.81 & 2.68 & 2.91 \\
$25 \%: 75 \%$ & 30 & 0.69 & 0.70 & 0.67 & 0.73 \\
$50 \%: 50 \%$ & 20 & 1.39 & 1.41 & 1.34 & 1.46 \\
zero $: 100 \%$ & 40 & - & - & - & - \\
\hline
\end{tabular}



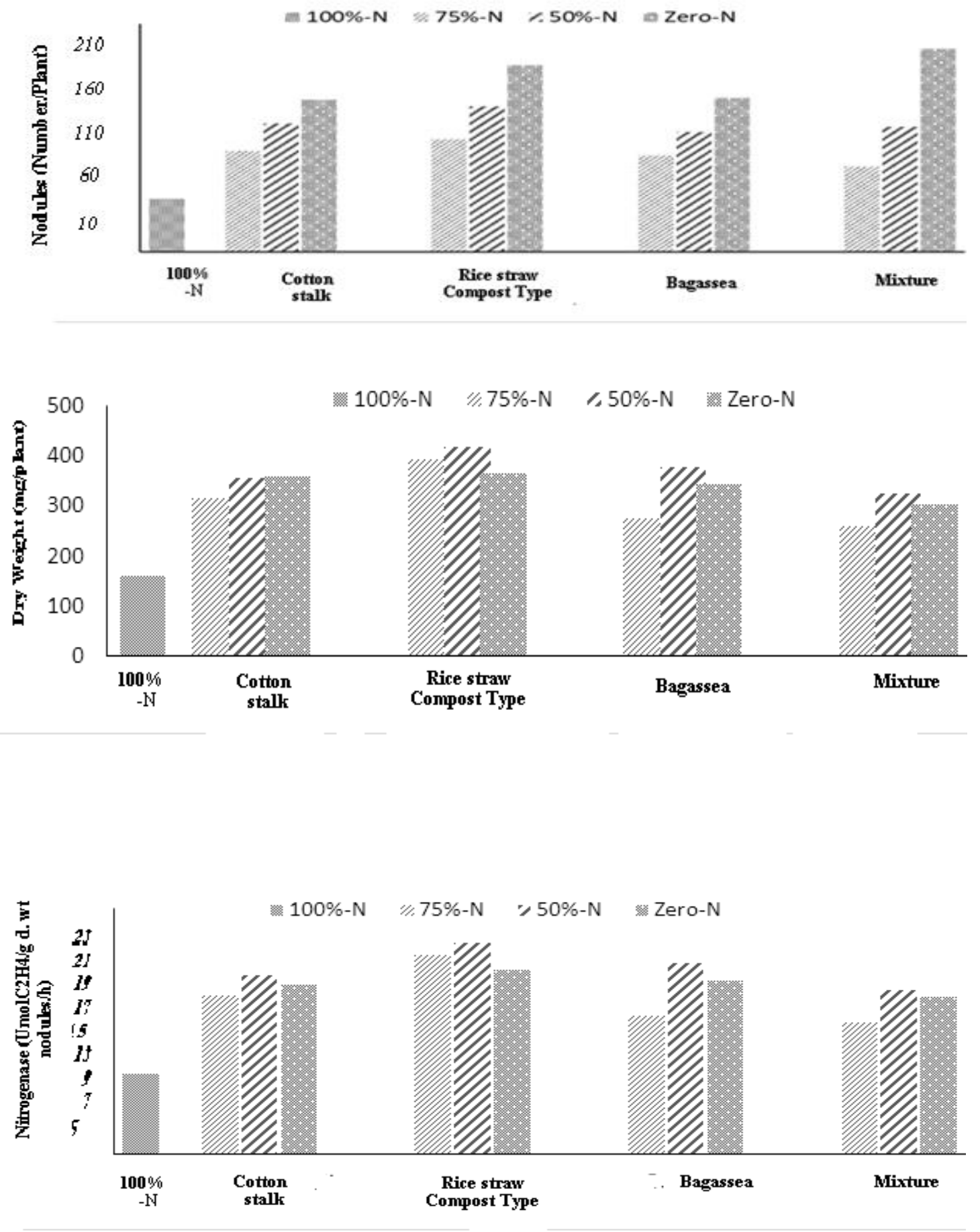

Fig. (1): Effect of organic-mineral nitrogen application on nodules number, dry weight and nitrogenase enzyme activity of peanut. 
Also Ibrahim et al. (2011) and Mohammadi et al. (2011) reported that the positive influence of organic manure application enhances the root growth and the uptake of nutrients, and thus improves the nodulation. This observation is in agreement with other studies where organic matter has been shown to increase the viable number of rhizobia and nodulation of peanut (Basu et al., 2008).

On the other hand, negative effect of high $\mathrm{N}$ rate fertilization on nodulation status may be due to the inhibition of the formation of infection threads or suppression of nitrogen fixation by nodules, (Ahmad, 2013 and Agha et al., 2004).

The application of organic fertilizer rich in nitrate did not suppress nodulation in the experimental sites though this $\mathrm{N}$-rich material with $\mathrm{C}: \mathrm{N}$ ratio less than $17: 1$ enhanced mineralization by microorganisms. However, the negative effect of $\mathrm{N}$ on nodulation was not observed. Lack of inhibition effect of $\mathrm{N}$ might be because of the attenuated effect of other essential nutrients found in the organic input (Burgos et al., 2006). Wu and Arima (1992) reported that $\mathrm{N}$ applied with other nutrients increased nodulation, whereas $\mathrm{N}$ applied alone reduced the nodule formation. This result suggests that application of medium rich $\mathrm{N}$ of organic fertilizer is essential to enhance nodulation in degraded and low fertile sand soils.

Concerning the effect of compost types or/and mineral $\mathrm{N}$-fertilizer on shoot dry matter and their $\mathrm{N}$-content it is clear that top-dressing with any compost type resulted in a significant increase in the plant vigor and $\mathrm{N}$-content of peanut in comparison to treatments received mineral-N only, except for bagasse compost type with zero and 100\% where shoot dry weight decreased (Figs. 2 and 3).

However, application of rice straw and cotton stalk composts resulted in the highest shoot biomass and its $\mathrm{N}$-content compared with the other compost types, particularly, when combined with $50 \%$ from mineral-N. The positive effect of organic substances on developing the plant vigor and accumulating the $\mathrm{N}$-content in their tissues may be attributed to increase the availability and translocation of nutrients, besides the high biological properties of the used composts, which contained the beneficial rhizobacteria leading to boost the promotive effect on plant vigor as confermid by many workers (Zhang et al., 1998; Lalande et al., 2000; El-Tahlawy, 2006 and AbdelWahab et al., 2009). Ojo et al. (2014) and Smith et al. (2015) recommended using various organomineral fertilizer composts as partial substitutes to mineral fertilizers in arid and semi-arid regions as

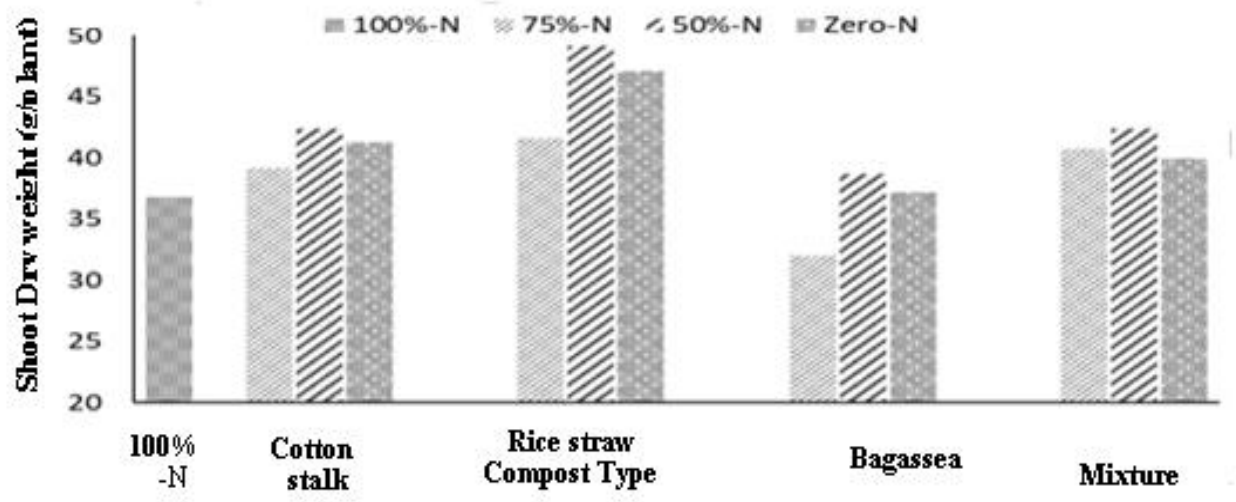

Fig. (2): Effect of organic-mineral nitrogen application on the dry weight of peanut shoot. 


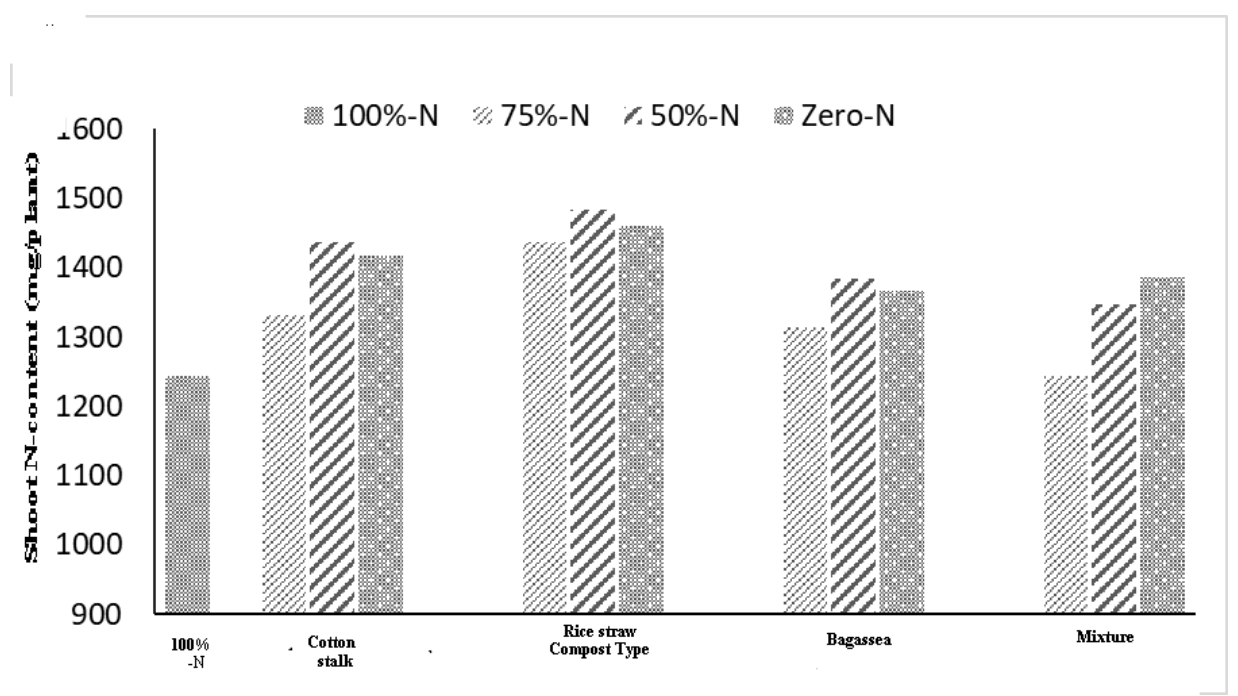

Fig. (3): Effect of organic-mineral nitrogen application on $\mathrm{N}$-content of peanut shoots.

source of nutrients, because these soils inherently have low organic matter and low mineralization due to high alkalinity and low rains. Because organic manures are characterized by slow release of nutrients, the complementary applications of organic manures with fast nutrient releasecharacterizing mineral fertilizers have been advocated (Rady et al., 2016). Rady (2011) and Riaz et al. (2015), also reported the beneficial effects of this practice in terms of improved crop productivity, soil fertility and sustainability, and balanced plant nutrition.

The improved growth characteristics of common bean plants produced as a result of increased application of organo-mineral fertilizer compost could be attributed to the enhanced decomposition of organic matter and mineralization of nutrients (Abdelhamid et al., 2004 and Ojo et al., 2014).

Various soil-microorganisms may benefit from some components of the organo-mineral fertilizer compost to increase their excretions of vitamins, growth substances, and antibiotics that can further promote plant growth (Osman and Rady, 2012 and Semida et al., 2014).

\subsection{Peanut yield and its components}

Peanut yield and its components as affected by different types of compost or/and different levels of mineral nitrogen fertilizer are shown in Table (4). Results showed that the peanut yield and its components achieved the highest values as a result of soil manuring with different types of bioenriched compost, particularly rice straw and cotton stalk composts. However, the types of compost existing in blend with mineral fertilizer at equal ratio $(50 \%$ and $50 \%$ ), recorded the highest values of peanut yield and its components. For instance, the values attained for seed yield $(\mathrm{kg} / \mathrm{fed})$; straw yield $(\mathrm{kg} / \mathrm{fed})$, pod number/plant, hundred seed weight (g), seed crude protein and straw crude protein contents (\%) as a result of addition of $50 \%$ rice straw compost in synergy with $50 \%$ mineral-N were $989.53,1366.2,27,27.93,87.92$ and 11.52. The corresponding values recorded in the case synergy of $50 \%$ cotton stalk compost with $50 \%$ mineral-N fertilizer were 980.0, 1352.5, 25, 86.74, 27.27 and 10.38 , respectively.

This shows the importance of organic fertilizer application to increase yield of peanut. This pronounced effect of organic inputs on final yield of peanut could be associated with the mineralization and releasing of nutrients from organic inputs at the late stage of the plants. This is in harmony with Khater et al. (2004) who reported positive benefits for improving soil characteristics under study due to compost amendments application where an improvement in the values of bulk density, hydraulic conductivity, soil consistence, available water content, organic matter 
Table (4): Influence of different compost types in synergy with different $\mathrm{N}$-levels on peanut yield and its components.

\begin{tabular}{|c|c|c|c|c|c|c|c|}
\hline \multirow{2}{*}{ Treatments } & \multirow{2}{*}{$\begin{array}{c}\text { Straw } \\
\text { yield } \\
\text { (kg/fed) }\end{array}$} & \multirow{2}{*}{$\begin{array}{c}\text { Pod } \\
\text { number/ } \\
\text { plant }\end{array}$} & \multirow{2}{*}{$\begin{array}{c}\text { Pod } \\
\text { yield } \\
\text { (kg/fed) }\end{array}$} & \multirow{2}{*}{$\begin{array}{c}\text { Seed } \\
\text { yield } \\
(\mathbf{k g} / \text { fed })\end{array}$} & \multirow{2}{*}{$\begin{array}{c}100- \\
\text { seed } \\
\text { weight } \\
(\mathrm{g})\end{array}$} & \multicolumn{2}{|c|}{$\begin{array}{c}\text { Crude protein } \\
(\%)\end{array}$} \\
\hline & & & & & & Straw & Seed \\
\hline \multicolumn{8}{|c|}{$100 \% \mathrm{~N}$ (40 kg N/fed) fertilizer } \\
\hline Without compost & 1198.8 & 22 & 1118.50 & 911.00 & 74.55 & 9.83 & 26.54 \\
\hline \multicolumn{8}{|c|}{$75 \% \mathrm{~N}(30 \mathrm{~kg} N /$ fed $)$ fertilizer $+25 \%$ compost } \\
\hline Cotton stalk compost & 1187.3 & 24 & 1119.07 & 911.70 & 81.80 & 9.91 & 26.34 \\
\hline Rice straw compost & 1199.9 & 24 & 1133.73 & 919.13 & 83.00 & $\mathbf{1 0 . 1 7}$ & 27.86 \\
\hline Bagasse compost & 1259.5 & 22 & 1131.63 & 914.68 & 80.65 & $\mathbf{1 0 . 1 5}$ & 27.17 \\
\hline Mixture compost & 1261.9 & 23 & 1110.67 & 923.67 & 82.42 & 10.08 & 26.88 \\
\hline \multicolumn{8}{|c|}{$50 \% \mathrm{~N}(20 \mathrm{~kg}$ N/fed $)$ fertilizer $+\mathbf{5 0 \%}$ compost } \\
\hline Cotton stalk compost & 1352.5 & 25 & 1183.00 & 980.00 & 86.74 & 10.38 & 27.27 \\
\hline Rice straw compost & 1366.2 & 27 & 1198.00 & 989.53 & 87.92 & 11.52 & 27.93 \\
\hline Bagasse compost & 1292.0 & 25 & 1174.21 & 963.12 & 85.18 & 11.10 & 27.42 \\
\hline Mixture compost & 1309.3 & 26 & 1178.67 & 956.67 & 86.38 & 11.25 & 26.95 \\
\hline \multicolumn{8}{|c|}{ Zero $\mathrm{N}$ fertilizer $+\mathbf{1 0 0 \%}$ compost } \\
\hline Cotton stalk compost & 1249.6 & 23 & 1178.55 & 957.19 & 85.52 & 11.10 & 27.62 \\
\hline Rice straw compost & 1258.1 & 24 & 1187.17 & 941.13 & 87.00 & 10.13 & 26.76 \\
\hline Bagasse compost & 1231.5 & 23 & 1162.78 & 939.77 & 85.11 & $\mathbf{1 0 . 1 7}$ & 27.11 \\
\hline Mixture compost & 1268.4 & 24 & 1159.18 & 951.59 & 86.72 & 11.13 & 26.81 \\
\hline LSD 0.05 & 7.6 & 1.5 & 5.9 & 5.6 & 3.2 & 0.4 & 1.2 \\
\hline
\end{tabular}

content and the released content of available nutrient i.e. $\mathrm{N}, \mathrm{P}, \mathrm{K}$ and $\mathrm{Cu}$ were recorded. Also findings by (Abdel-Wahab et al., 2009), reflected the essential role of distinct bio-organic substances in improving peanut productivity in sandy soil, which might be elucidated by the vital role of bioorganic materials in improving the physical, chemical and biological properties of sandy soil, reflected on plant nutritional status leading to support plant growth and consequently augmentation of peanut yield and its components.

The benefits of organic and inorganic fertilizer application in combination with rhizobia on the agronomic productivity of food legumes have been previously reported in chickpea (Namvar et al., 2013;). Also, Shahzad et al. (2013), demonstrated a significant increase in soil nutrients including available $\mathrm{P}$ by organic matter application.

The increase in pod and seed yield treated with rice straw might be due to improved soil condition coupled with large surface area of straw at low dosage which promotes faster decay and release of nutrients. This is in agreement with (Jagdev and Singh 2000 and Abdul Aziz et al., 2016), who reported that rice straw had $\mathrm{C} / \mathrm{N}$ ratio of $1: 1$, which is a clear indication that the material can decompose rapidly. Its high organic matter and low organic carbon concentration were adequate for the growth and development of groundnut.

From these results, it could be concluded that the synergy between compost enriched with natural amendments and rhizobacteria as half dose of $\mathrm{N}$-fertilizer source and mineral-N fertilizer (as 
second source) led to increase the growth and productivity of peanut under sandy soil conditions.

This fertilization pattern may be considered the most effective strategy for reducing chemical fertilizer, conserving soil fertility and supporting the sustainable agriculture system under newly reclaimed soils for producing peanut.

\section{REFERENCES}

Abdalla A.A., El-Howeity M.A. and Desoky A.H. (2009). Response of peanut crop cultivated in newly reclaimed soil to inoculation with plant growth promoting rhizobacteria. Minufiya J. Agric. Res., 34: 2281- 2304.

Abdel-Hafez G.A. and Abo El-Soud A.A. (2007). Response of two soybean cultivars to different levels of organic fertilizer, J. Agric. Scie., Mansoura Univ., 32:85728588.

Abdelhamid M.T. Horiuchi T. and Oba S. (2004) Composting of rice straw with oilseed rape cake and poultry manure and its effects on faba bean (Vicia faba L.) growth and soil properties. Bioresour. Tech., 93:183-189.

Abdel-Wahab A.F.M. (2008). Evaluation of enriched compost and its role in synergy with rhizobacteria and $\mathrm{N}$-fertilization for improving maize productivity in sandy soil. Arab Univ. J. Agric. Sci., 16: 319-334.

Abdel-Wahab A.F.M., Biomy A.M.M. and ElFarghal W.M. (2009). Co-composting of plant residues and their utility with micronutrients to enhance productivity of faba bean Rhizobium symbiosis under sandy soil conditions. Egypt J. Appl. Sci., 24: 343368.

Abdel-Wahab A.F.M., Biomy A.M.M. and ElFarghal W.M. (2003). Effect of some natural soil amendments on biological nitrogen fixation, growth and green yield of pea plant grown on sandy soil. Fayoum J. Agric. Res. and Dev., 17: 47-54.

Abdul Aziz A., Bolaji U.O. and Emmanuel O.E. (2016). Rice straw: a valuable organic manure for soil amendment in the cultivation of groundnut (Arachis hypogaea) Environ. Exper. Biol., 14: 205-211.

Agha S.K., Oad F.C. and Buriro U.A. (2004). Yield and yield components of inoculated and un-inoculated soybean under varying nitrogen levels. Asian J. plant Sci., 3: 370371.

Ahmed F.E. (2013). Interactive effect of nitrogen fertilization and Rhizobium inoculation on nodulation and yield of soybean (Glycine $\max$ L. Merrill). Global J. Biol. Agric. Health Sci., 2: 169-173.

Ayuso M., Hernandez T., Garcia C. and Pascual J.A. (1996). Stimulation of barley growth and nutrient absorption by humic substances originating from various organic materials. Bioresource Techn., 57: 251-257.

Basu M., Bhadoria P.B.S. and Mahapatra S.C. (2008). Growth, nitrogen fixation, yield and kernel quality of peanut in response to lime, organic and inorganic fertilizer levels. Bioresour Techn., 99:4675-4683.

Burgos P., Madejon E. and Cabrera F. (2006). Nitrogen mineralization and nitrate leaching of a sandy soil amended with different organic wastes. Waste Manage. Res., 24:175-218

Chen Y., Clapp C.E., Magan H. and Cline V.W. (1999). Stimulation of plant growth by humic substances: Effect on iron availability. In: Davies, G. Ghabbour, E.A. (eds.). Understanding humic substances; "Advanced Methods, Properties and "Application. Royal Society of Chemistry, Cambridge, U K.

Datt N., Dubey Y.P. and Rohina C. (2013). Studies on impact of organic, inorganic and integrated use of nutrients on symbiotic parameters, yield, quality of French-bean (Phaseolus vulgaris L.) vis-à-vis soil properties of an acid alfisol. African. J. Agric. Res., 8: 2645-2654.

Desoky A.H., El-Saw W.A. and Taher H.M.E. (2011). Enhancement of peanut growth and productivity by inoculation with Bradyrhizobium and some rhizobacteria under graded levels of mineral $\mathrm{N}$ fertilization in newly soils. Egypt. J. Appl. Sci., 26: 409-427.

Doran J. (1995). Building soil quality. In: Proceedings of the 1995 Conservation Workshop on Opportunities and Challenges in Sustainable Agriculture. Red Dear, Alta, 
Canada, Alberta Tillage Conservation Society and Alberta Agriculture Conservation, development Branch. pp. 151-158.

El-Tahlawy Y.A. (2006). The microbial impact on productivity of some medicinal plants. M.Sc. Thesis, Fac. Agric., Ain Shams Univ., Egypt.

Fageria N.K., Baligar V.C. and Jones C. (1997). Growth and mineral nutrition of field crop. $2^{\text {nd }}$ Ed. Marcel Dakker, Inc, New York, USA $1001 \mathrm{~K}$. pp: 494.

FAO (2013). Food and Agriculture Organization of the United Nations. Giews country briefs.

http://faostat.fao.org/site/567/default.aspx\#ancor.

Hardy R.W.F., Burns R.C. and Holsten R.O. (1973). Applications of the acetyleneethylene assay for measurement of nitrogen fixation. Soil Biol. Biochem., 5: 47-81.

Hoitink H.A.J. and Grebus M.E. (1994). Status of biological control of plant diseases with composts. Compost Sci. Util., 2: 6-12.

Ibrahim M., Yamin M., Sarwar G. Anayat A., Habib F., Ullah S. and Rehman S. (2011). Tillage and farm manure affect root growth and nutrient uptake of wheat and rice under semi-arid conditions. Appl. Geochem., 26:194-197.

Jagdev S. and Singh K.P. (2000). Effect of Azotobacter, FYM and fertility levels on yield, nitrogen recovery and use efficiency in spring sunflower. Haryana J. Agron., 16: 57-60.

Keeling A.A., McCallum K.R. and Beekwith C.P. (2003). Mature green waste compost enhances growth and nitrogen uptake in wheat (Triticum aestivum L.) and oilseed rape (Brassica napus L.) through the action of water extractable factors. Bioresource Techn., 90: 127-132.

Khater E.A., Ibrahim S.B. and Awadalla A.A. (2004). Utilization of some form organic wastes for improving soil productivity of newly reclaimed areas at El-Fayoum Governorate, Egypt. Egypt. J. Soil Sci., 44: 333-35.

Lalande R., Gagnon B., Sinard R.R. and Cote D. (2000). Soil microbial biomass and enzyme activity following liquid hog manure application in long term field trial. Can. J. Soil Sci., 80: 263-269.
Mahrous N.M., Safina S.A., Abo Taleb H.H. and El-Behlak S.M.E. (2015). Integrated use of organic, inorganic and bio-fertilizers on yield and quality of two peanut (Arachis hypogaea L.) cultivars grown in a sandy saline soil. American-Eurasian J. Agric. \& Environ. Sci., 15 (6): 1067-1074.

McCallum K.R. (2000). An evaluation of green waste compost in the growth and yield of wheat. Ph.D. Thesis, Harper Adams University College. U. K.

Mohammadi K, Ghalavand A. and Aghaalikhani M. (2011). Effect of different soil fertility strategies on absorption metabolism and molecular nitrogen fixation in chickpea (Cicer arietinum). Iran J. Pazhuhesh Sazandegi, 91:78-89.

Namvar A., Seyed R.S., Khandan T. and Jafari M.M. (2013) Seed inoculation and inorganic nitrogen fertilization effects on some physiological and agronomical traits of chickpea (Cicer arietinum L.) in irrigated condition. J Central Eur. Agric., 14:28-40.

Ojo J.A., Olowoake A.A. and Obembe A. (2014). Efficacy of organo-mineral fertilizer and unamended compost on the growth and yield of watermelon (Citrullus lanatus Thumb) in Ilorin Southern Guinea Savanna zone of Nigeria. Int. J. Recycl. Org. Waste Agric., 3:121-125.

Osman A.Sh. and Rady M.M. (2012). Ameliorative effects of sulphur and humic acid on the growth, antioxidant levels, and yields of pea (Pisum sativum L.) plants grown in reclaimed saline soil. J. Hort. Sci. Biotech., 87:626-632.

Owis A.S., El-Etr W.M., Badawi F.Sh.F., Abo Elsoud A.A. and Abdel-Wahab A.F.M. (2016). Bio-processing the crop residues with different amendments for producing high quality compost. Int'l. J. Chem. Tech. Res., 9:43-54.

Page A.L., Miller R.H. and Keeney D.R. (1982). Methods of Soil Analysis. II- Chemical and Microbiological Properties. Soil Sci. Amer., Madison Wisconsin, USA.

Piper C.S. (1950). Soil and Plant Analysis. $1^{\text {st }}$ Ed. Interscience Publishers Inc., New York, USA. pp: 30-229. 
Rady M.M. (2011). Effects on growth, yield, and fruit quality in tomato (Lycopersicon esculentum Mill.) using a mixture of potassium humate and farmyard manure as an alternative to mineral-N fertilizer. J. Hortic. Sci. Biotechnol., 86:249-254.

Rady M.M., Semida W.M., Khaulood A. Hemida and Abdelhamid M.T. (2016) The effect of compost on growth and yield of Phaseolus vulgaris plants grown under saline soil Int. J. Recycl. Org. Waste Agric., 5:311-321.

Riaz A., Younis A., Ghani I., Tariq U. and Ahsan M. (2015). Agricultural waste as growing media component for the growth and flowering of Gerbera jamesonii cv. hybrid mix. Int. J. Recycl. Org. Waste Agric., 4:197-204.

Semida W.M., Abd El-Mageed T. A. and Howladar S.M. (2014). A novel organomineral fertilizer can alleviate negative effects of salinity stress for eggplant production on reclaimed saline calcareous soil. Acta. Hort., 1034: 493-499.

Shahzad S.M., Khalid A. Arif M.S., Riaz M., Ashraf M., Iqbal Z. and Yasmeen T. (2013). Co-inoculation integrated with $\mathrm{P}$-enriched compost improved nodulation and growth of chickpea (Cicer arietinum L.) under irrigated and rainfed farming systems. Biol. Fertil. Soils, 50: 1-12.

Shehata S.M. (2001). Effect of some organic wastes application on growth, chemical contents and yield of squash plant. J. Agric. Sci., Mansoura Univ., 26: 5695-5704.
Smith G.H., Chaney K., Murray C. and Le M.S. (2015). The effect of organo-mineral fertilizer applications on the yield of winter wheat, spring barley, forage maize and grass cut for silage. J. Environ. Protect. 6:103109.

Snedecor G.W. and Cochran W.G. (1980). "Statistical Methods " $7^{\text {th }}$ Ed., Iowa State Univ. Press, Ams., Iowa,USA, pp. 255-269.

Sulfab H.A., Mukhtar N.O., Hamad M.E. and Adam A.I. (2011). Effect of bio-organic and mineral nitrogen starter dose on growth and production of groundnuts (Arachis hypogaea L.) in Malakal area. J. Sci. Techn., 12: 13-22.

Tiwari K.N. (2002). Nutrient management for sustainable agriculture. J. Indian Soc. Soil Sci., 50:374-397.

Vessey J.K. and Buss T.J. (2002). Bacillus cereus UW85 inoculation effects on growth nodulation and $\mathrm{N}$-accumulation in grain legumes. Controlled environment studies. Can. J. Plant Sci., 82: 282-290.

Wu J. and Arima Y. (1992) Effect of Rhizobium inoculation and application of NPK fertilizer on the growth and nitrogen fixation of field-grown Chinese milk vetch. Soil Sci. Plant Nutr., 38:75-84.

Zhang W., Han D.Y., Dick W.A., Davis K.R. and Hoitink J. (1998). Compost and compost water extract induced systemic acquired resistance in cucumber and arabidopsis. Phytopathol., 88: 450-455. 
تثبيت النيتروجين تكافليا عند تطبيق التكامل بين النيتروجين العضوي ـ المعدني في نباتات الفول السوداني في الأراضي الرملية هند مصطقي العجيمي - ياسر عربي الطحلاوي - سعاد يوسف سري السيا

قسم بحوث الميكروبيولوجيا الزر اعيةـ معهد بحوث الأر اضى و المياه و البيئة ـ مركز البحوث الزر اعية ـ الجيزة ـ مصر

\section{ملخص}

اجريت تجربة حقلية فى تربة رملية بمحطة الإسماعيلية للبحوث الزراعية بمحافظة الإسماعيلية خلال صيف 2016 لار اسة تأثنير

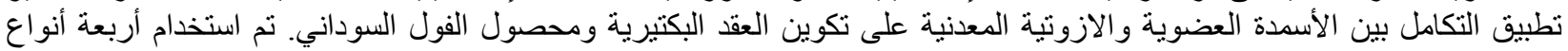

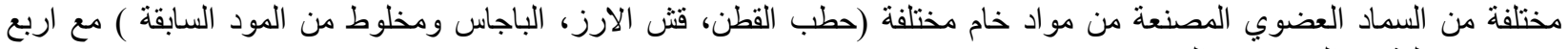

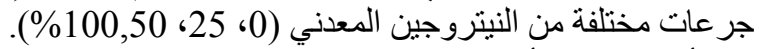

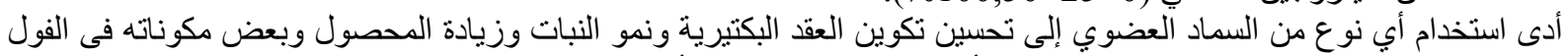

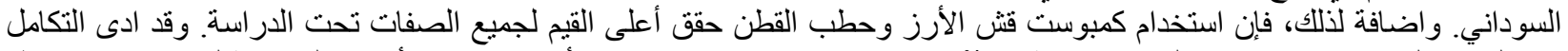

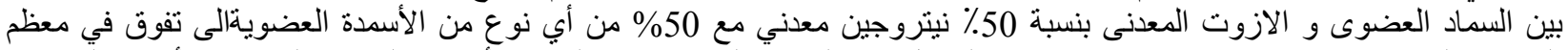

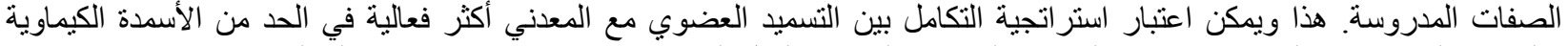

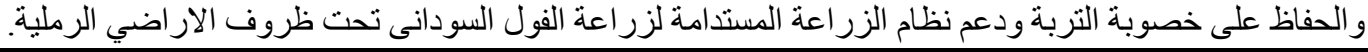
المجلة العلمية لكلية الزراعة - جامعة القاهرة - المجلا (68) العدد الثالث (يوليو 2017 ) :344-333. 